\title{
Inheritance of White Mold Resistance in Phaseolus vulgaris $\times$ P. coccineus Crosses
}

\author{
Howard F. Schwartz and Kristen Otto, Department of Bioagricultural Sciences and Pest Management, Colorado \\ State University, Fort Collins 80523-1177; and Henry Terán, Margarita Lema, and Shree P. Singh, Department of \\ Plant, Soil and Entomological Sciences, University of Idaho, Kimberly 83341-5076
}

\begin{abstract}
Schwartz, H. F., Otto, K., Terán, H., Lema, M., and Singh, S. P. 2006. Inheritance of white mold resistance in Phaseolus vulgaris $\times$ P. coccineus crosses. Plant Dis. 90:1167-1170.

The fungus Sclerotinia sclerotiorum, cause of white mold, is known to attack $>400$ plant species. It is a widespread problem in dry bean (Phaseolus vulgaris) in the United States, causing $>30 \%$ average yield losses. Low to moderate levels of resistance are found in dry bean. However, some accessions of $P$. coccineus (commonly known as scarlet runner bean) possess a relatively higher level of resistance. Our objective was to verify the reaction of 13 known white mold-resistant $P$. coccineus germ plasms and determine inheritance of resistance in accessions PI 433246 and PI 439534. Pinto Othello was crossed with PI 433246, and the resulting interspecific $F_{1}$ was backcrossed onto Othello and allowed to produce $\mathrm{F}_{2}$ seed. Similarly, pinto UI 320 was crossed with PI 439534. The $F_{1}$ was backcrossed onto UI 320 and allowed to produce $F_{2}$ seed. The two parents, $F_{1}, F_{2}$, and backcross to dry bean of each set were evaluated in the greenhouse using the straw test at Fort Collins, CO in 2004. All 13 P. coccineus accessions and the two $\mathrm{F}_{2}$ also were evaluated using the modified petiole test at Kimberly, ID in 2005. All 13 P. coccineus accessions were variable in a 2002 straw test when rated for white mold reaction on a 1-to-9 scale, because the mean disease score ranged from 1.9 for PI 433246 to 4.4 for PI 189023 and 8.8 for the susceptible check Bill Z. For the petiole test, when rated on a 1-to-9 scale, the accessions exhibited an intermediate white mold score of 4 or 5 in 2005. In 2004, the susceptible check Othello exhibited a mean score of 7.9 compared with 3.4, 3.2, and 2.1 for PI 433246, UI 320, and PI 439534, respectively. The white mold reaction of PI 433246 and PI 439534 was dominant in their respective $F_{1}$. The $F_{2}$ segregation further indicated that white mold resistance in PI 433246 and PI 439534 was controlled by a single dominant gene. These two and other white moldresistant $P$. coccineus accessions and selected breeding lines from the interspecific crosses should be useful for future improvement of white mold resistance of pinto and other market classes of dry and green or snap bean.
\end{abstract}

Additional keywords: integrated pest management

White mold (caused by Sclerotinia sclerotiorum (Lib.) de Bary) is endemic, widely distributed, and one of the most devastating diseases of the common (dry and green) bean (Phaseolus vulgaris L.) in the United States and other cool, humid regions of the world (24). Average yield losses are $>30 \%$, but individual losses may exceed $90 \%(8,21)$. White mold incidence is increasing in the western United States with the expansion of overhead irrigation systems. Sclerotia survive in the soil and plant debris for years. The pathogen is seed transmitted and reduces seed quality.

Corresponding author: H. F. Schwartz

E-mail: Howard.Schwartz@ColoState.Edu

The use of trade, firm, or corporation names in this publication is for the information and convenience of the reader. Such use does not constitute an official endorsement or approval by the United States Department of Agriculture or the Agricultural Research Service of any product or service to the exclusion of others that may be suitable.

Accepted for publication 27 April 2006

DOI: 10.1094/PD-90-1167

(C) 2006 The American Phytopathological Society
Controlling or managing white mold through chemicals and cultural practices is often inadequate, and use of chemicals increases production costs for growers and minimizes their competitive edge in the national and international market place. Use of resistant cultivars is pivotal to any effective and economical long-term integrated pest management strategy to control white mold. However, only low to moderate levels of resistance to white mold exist in a few Middle American (e.g., 'ICA Bunsi,' synonymous with ExRico 23) and Andean (e.g., A 195, G 122, MO 162, and PC 50) dry bean and green bean germ plasms (e.g., NY6020-4) (12,25). On the other hand, some accessions of the Phaseolus sp. in the secondary gene pool, such as $P$. coccineus L., are known to possess much higher levels of resistance than the common bean (5). White mold-resistant dry bean (9) and P. coccineus (2) are less sensitive to oxalate.

White mold resistance in dry bean is inherited quantitatively $(15,19)$. Despite a continuous variation for white mold reaction among 70 recombinant inbred line (RI) populations in both the greenhouse and field screening environments, Park et al. (19) reported random amplified polymorphic DNA (RAPD) markers linked with as many as nine quantitative trait loci (QTL) for partial physiological resistance (PPR) for white mold in the greenhouse in a PC 50/XAN 159 dry bean population. Six of the seven QTL for partial field resistance (PFR) were found in the same chromosome regions as the QTL for PPR. Furthermore, two of the seven QTL for PFR were associated with canopy porosity over the furrow, which may have contributed to white mold avoidance. These markers were located on chromosomes 3, 4, 6, and 10. In a similar region on chromosome 4 , Miklas et al. (16) identified the Phs locus linked with a major QTL for white mold resistance in the greenhouse straw test $(38 \%)$ and field resistance $(26 \%)$ in the A 55/G 122 dry bean population. They reported another QTL on chromosome 2 for canopy porosity $(34 \%)$ and disease avoidance (18\%) in the field that mapped at the fin locus for the determinate growth habit. Miklas et al. (13) also identified two QTL in the 'Benton'/NY 6020-4 green bean population. The QTL from Benton was located on chromosome 1 and that from NY 6020-4 (responsible for 38\% variation in white mold resistance) associated with increased internode length was located on chromosome 3. Kolkman and Kelly (10) reported that resistance and avoidance QTL from the ICA Bunsi/Newport dry bean population were located on chromosomes 4 and 9. Thus, >12 QTL controlling resistance to white mold, mostly with small to modest effects, are distributed on 8 of the 11 chromosomes $(10,13,16,19)$.

In contrast to the above reports of quantitative inheritance, Genchev and Kiryakov (4) found incomplete dominance of resistance in the $F_{1}$, but the $F_{2}$ segregated into 3 susceptible to 1 resistant in the greenhouse test, indicating a recessive gene control in the dry bean breeding line A 195. However, in the field, a monogenic dominant resistance was observed. Abawi et al. (1) also reported that a single dominant allele controlled resistance to white mold in a $P$. vulgaris/P. coccineus population. Molecular markers for these major dominant and recessive resistance alleles have not been identified and mapped yet. Myers and Stotz (18) reported that two or three recessive genes controlled inheritance of white mold resistance in susceptible $\times$ resistant $P$. coccineus crosses.

White mold resistance from $P$. coccineus has been introgressed into dry bean (14). 
Although comparative data is not available, there is some evidence that the level of white mold resistance introgressed in dry bean, in general, is lower than that of $P$. coccineus. As part of the United States Department of Agriculture (USDA) Sclerotinia Initiative, we screened most of the $P$. coccineus accessions that were reported by Gilmore et al. (5) to be resistant to white mold (Table 1). Of 13 P. coccineus accessions, we selected PI 433246 and PI 439534 to study inheritance and introgress their white mold resistance into dry bean. The objective of this study was to determine the inheritance of resistance in susceptible $P$. vulgaris $\times$ resistant $P$. coccineus crosses.

\section{MATERIALS AND METHODS}

Resistance in $P$. coccineus and parental selections. In 2002, we obtained seed of 13 recently reported white moldresistant $P$. coccineus (5) accessions from the USDA-Agricultural Research Service (ARS), Pullman, WA. These, along with susceptible pinto cv. Bill Z, were screened in the greenhouse using the straw test as described below at Fort Collins, CO (Table 1). On average, 13 plants per accession were grown as 2 plants per 15 -cm-wide plastic pot of MetroMix 200 potting soil (Grace Sierra Horticultural Products Company, Milpitas, CA) and scored for white mold reaction as described below. Each plant was inoculated with a 3- to 5-day-old mycelial plug from a colony of $S$. sclerotiorum isolate $\mathrm{CO}-\mathrm{S} 20$ (pinto bean isolate from northern Colorado) grown in the dark on PDA $(1.5 \%)$ at $22^{\circ} \mathrm{C}$. The original $\mathrm{CO}-\mathrm{S} 20$ isolate was maintained in the refrigerator at $4^{\circ} \mathrm{C}$ as PDA-produced sclerotia; a sclerotium was surface disinfested with $0.6 \%$ sodium hypochlorite for $30 \mathrm{~s}$ and transferred aseptically to PDA to initiate a supply of fresh mycelium for each experiment in Colorado and Idaho. Plants were inoculated using the straw test by removing the growing tip of the main stem with scissors. A $3-\mathrm{cm}$ length of plastic straw (6 $\mathrm{mm}$ in diameter) had one end melted shut, and the open end was used as a cork borer to cut up discs of agar and mycelium from a 3- to 5-day-old culture of white mold $(17,20)$. One piece of straw inoculum then was placed over the exposed end of the plant stem. Individual plants were rated for their reaction to white mold (extent of water-soaked tissue or evidence of fungal colonization as white mycelium on infected tissue) on a 1-to-9 scale after 10 to 14 days of incubation in a mist chamber with diffuse sunlight at 22 to $25^{\circ} \mathrm{C}$. The rating scale criteria were: $1=$ no obvious sign of disease, but the stem was infected adjacent to agar inoculant when the straw was removed for inspection; $3=$ invasion of the stem for several centimeters or to the first lower stem node, but no further; $5=$ invasion past the first lower node, but progressing slowly; $7=$ invasion to the second lower node or further, but not total collapse of the plant; $9=$ total plant collapse (death).

Based on results from this study and previous reports, $P$. coccineus accessions PI 433246 and PI 439534 were selected for interspecific hybridization with white mold-susceptible pinto bean cultivars (the largest market class of dry bean in North America). In 2005, the set of 13 P. coccineus accessions also were screened in the greenhouse at Kimberly using a modified petiole test, in which the mycelial plug was allowed to stay on the tip of the inoculated petiole $(7 \mathrm{~cm}$ of the trifoliolate leaf at the fifth or sixth node) until it fell off days later or the plant matured $(3,11)$. Six plants per accession were evaluated.

Pinto bean cvs. Othello and UI 320, type II and III growth habit (22), respectively, were selected for the inheritance study. Both Othello and UI 320 are early maturing in the western United States. Moreover, Othello is widely adapted despite its susceptibility to most bacterial, viral, and fungal diseases, including white mold. However, Othello carries the recessive $b c$ $2^{2}$ gene that imparts resistance to some strains of Bean common mosaic virus (BCMV, a potyvirus). UI 320 is resistant (possesses the $I$ gene) to all known strains of BCMV and some races of Uromyces appendiculatus (Pers.:Pers.) Unger, the cause of bean rust. The scarlet runner bean accession PI 433246 is highly photoperiod sensitive (taking 82 days to flower even in a 12-h daylight environment) with indeterminate extreme climbing growth habit type IV from Guatemala. PI 433246 has scarlet color flowers and a mixture of large seed of brown, purple, and red in color. PI 439534 also is indeterminate climbing growth habit type IV with scarlet flowers, but it is photoperiod insensitive (taking 38 days to flower in a 15-h daylight environment). PI 439534 is from The Netherlands and has large, pink-spotted seed.

Inheritance of resistance in $P$. vulgaris $\times$ P. coccineus crosses. During 2002 and 2003, Othello was crossed with PI 433246, and the resulting interspecific $F_{1}$ was backcrossed onto Othello and allowed to produce $F_{2}$ seed. Similarly, UI 320 was crossed with PI 439534. The $\mathrm{F}_{1}$ was backcrossed on to UI 320 and allowed to produce $F_{2}$ seed. The four parents and $F_{1}, F_{2}$, and backcross to the dry bean involving each $P$. coccineus accession were grown in the greenhouse at Fort Collins, $\mathrm{CO}$ in 2004. The frequency distribution and mean disease scores for the $F_{2}$ and backcrosses were determined after conducting the straw test as described above. The two $F_{2}$ of interspecific crosses also were evaluated, using the modified petiole test as

Table 1. Disease scores for 13 Phaseolus coccineus accessions evaluated for white mold resistance in a greenhouse using the straw test at Fort Collins, CO in 2002 and the modified petiole test at Kimberly, ID in 2005

\begin{tabular}{|c|c|c|c|c|c|c|c|c|}
\hline \multirow[b]{3}{*}{ Identification $^{\text {b }}$} & \multirow[b]{3}{*}{ No. of plants } & \multicolumn{6}{|c|}{ Colorado } & \multirow{3}{*}{$\begin{array}{c}\text { Idaho } \\
\text { Mean score }\end{array}$} \\
\hline & & \multicolumn{5}{|c|}{ Plants with white mold scores $(\%)^{\mathrm{a}}$} & \multirow[b]{2}{*}{ Mean score } & \\
\hline & & 1 & 3 & 5 & 7 & 9 & & \\
\hline PI 189023 & 16 & 0 & 50.0 & 37.5 & 6.3 & 6.3 & 4.4 & 4.0 \\
\hline PI 201304 & 12 & 33.3 & 33.3 & 8.3 & 25.0 & 0 & 3.5 & 5.0 \\
\hline PI 201320 & 15 & 13.3 & 66.7 & 20.0 & 0 & 0 & 3.1 & 5.0 \\
\hline PI 311985 & 15 & 33.3 & 60.0 & 6.7 & 0 & 0 & 2.5 & 4.0 \\
\hline PI 317551 & 14 & 42.9 & 35.7 & 14.3 & 7.1 & 0 & 2.7 & 4.0 \\
\hline PI 433236 & 12 & 25.0 & 58.3 & 8.3 & 0 & 8.3 & 3.2 & 4.0 \\
\hline PI 433237 & 13 & 23.1 & 61.5 & 15.4 & 0 & 0 & 2.9 & 4.0 \\
\hline PI 433242 & 15 & 20.0 & 60.0 & 20.0 & 0 & 0 & 3.0 & 4.0 \\
\hline PI 433246 & 7 & 57.1 & 42.9 & 0 & 0 & 0 & 1.9 & 4.0 \\
\hline PI 433247 & 11 & 0 & 90.9 & 9.1 & 0 & 0 & 3.2 & 4.0 \\
\hline PI 433250 & 14 & 57.1 & 28.6 & 7.1 & 0 & 7.1 & 2.4 & 5.0 \\
\hline PI 433251 & 16 & 0 & 87.5 & 12.5 & 0 & 0 & 3.3 & 4.0 \\
\hline PI 439534 & 10 & 0 & 80.0 & 20.0 & 0 & 0 & 3.4 & 5.0 \\
\hline Bill Z (susceptible) & 9 & 0 & 0 & 0 & 11.1 & 88.9 & 8.8 & 9.0 \\
\hline Total/mean & 286 & 16.3 & 60.0 & 17.3 & 2.4 & 1.0 & 3.2 & 4.6 \\
\hline
\end{tabular}

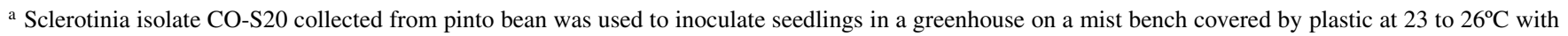
diffuse lighting. Reactions were scored on a 1-to- 9 scale at 5 to 7 days post-inoculation, where $1=$ symptomless and $9=$ severely diseased.

${ }^{\mathrm{b}}$ All PI are $P$. coccineus and Bill $\mathrm{Z}$ is a $P$. vulgaris cultivar; PIs in bold indicate resistant parent selected for crosses.

${ }^{\mathrm{c}}$ Mean of six plants for each genotype. 
described above, in the greenhouse at Kimberly, ID. A 48-h-old mycelial plug on a pipette tip was used to inoculate each petiole. The frequencies in $F_{2}$ and backcrosses were grouped into resistant (receiving scores of 1 to 5) and susceptible (6 to $9)$. The data were subjected to the $\chi^{2}$ test to determine the inheritance of resistance to white mold in interspecific progenies derived from crosses of $P$. coccineus accessions PI 433246 and PI 439534 with pinto cvs. Othello and UI 320, respectively. Because segregation ratios in $F_{2}$ at Fort Collins and Kimberly were similar, data were pooled for a combined analysis.

\section{RESULTS AND DISCUSSION}

Resistance in $P$. coccineus and parental selections. Based on the mean disease score, all $13 P$. coccineus accessions were either resistant (disease scores $\leq 3$ ) or intermediate (disease scores $>3$ and $\leq 6$ ) to white mold using the straw test in the greenhouse at Fort Collins, CO (Table 1). Although white mold scores were relatively higher in the greenhouse at Kimberly, ID because slightly different inoculation and evaluation methods were used, all of the accessions exhibited significantly less white mold infection than the susceptible check. Thus, these results supported the earlier report by Gilmore et al. (5). Nonetheless, variation for disease reaction within each accession was conspicuous. Some accessions (e.g., PI 433250) with highly resistant plants and a mean white mold score of $<3$ also had a few highly susceptible plants. $P$. coccineus and other species in the secondary gene pool are characterized by a considerable amount of outcrossing because of the extrorse stigma and large, scarlet flowers which attract pollinating insects. Because a sample of seed from the USDA-ARS working collection at Pullman, WA was used for screening without prior selection, some withinaccession variation for white mold reaction and other characters was expected. Thus, it is advisable to use pure lines from highly resistant selected plants for future breeding and genetics studies.

Inheritance of resistance in $P$. vulgaris $\times P$. coccineus crosses. Othello, with a mean white mold score of 7.9 , was the only susceptible parental genotype (Table 2). To our pleasant surprise, UI 320, with a mean disease score of 3.2 , was intermediate. Nonetheless, both Othello and UI 320 exhibited a wide range of scores. For example, of 33 plants scored for Othello, 6 showed an intermediate reaction. Similarly, 4 of 36 plants of UI 320 were susceptible. P. coccineus accession PI 433246 was intermediate and PI 439534 was resistant to white mold. The reactions of PI 433246 and 439534 varied somewhat between trials (Tables 1 and 2), possibly due to different environmental conditions in an older greenhouse (daily temperatures were 2 to $3^{\circ} \mathrm{C}$ higher) available for the initial screening of resistant parents. However, the relative resistance of these lines was confirmed in the newer greenhouse and environment used for all subsequent evaluations in the critical inheritance study.

The Othello/PI 433246 interspecific $\mathrm{F}_{1}$ had an intermediate and UI 320/PI 439534 had a resistant reaction, suggesting that both reactions to white mold in the two $P$. coccineus accessions were controlled by dominant alleles. Although fewer plants were screened in the greenhouse and a slightly different inoculation method was used at Kimberly compared with Fort Collins, the $F_{2}$ segregation ratios were similar in both environments. Thus, the combined $\mathrm{F}_{2}$ of Othello/PI 433246 segregated into 36 resistant to 10 susceptible, giving a good fit to a 3:1 resistant:susceptible ratio $(P=0.61)$. This segregation further suggested that the white mold resistance in PI 433246 was controlled by a single dominant allele. However, in the backcross to Othello, one would have expected a 1:1 resistant:susceptible segregation ratio. Instead, there were 27 susceptible and 7 resistant plants; thus, an excess of the susceptible progenies. This might have occurred because of an excess of Othello gametes giving distorted segregation or the tendency of the interspecific hybrid to revert to the parental common bean genotype, especially when backcrossed onto it. Occurrence of lethal, crippled, and partially sterile progenies and a marked reduction in population size in the early generations of $P$. vulgaris $\times P$. coccineus crosses are common in tropical as well as temperate environments (23). Abawi et al. (1) and Myers and Stotz (18) also observed stunted, dwarf lethal, and sterile plants, and encountered similar problems with viable seed recovery in the $\mathrm{F}_{1}$ and $\mathrm{F}_{2}$ of $P$. vulgaris $\times P$. coccineus crosses.

Of 39 pooled $\mathrm{F}_{2}$ plants of UI 320/PI 439534, 9 were susceptible to white mold, and all others had a resistant or intermediate reaction. This gave a good fit to a $3: 1$ resistant:susceptible ratio $(P=0.78)$, indicating that the resistance in PI 439534 also was controlled by a single dominant allele. However, only 1 of 31 plants in the backcross to UI 320 was susceptible, whereas one would have expected either a ratio of 1:1 resistant:susceptible, all resistant or intermediate to none susceptible, or $3: 1$ resistant and intermediate:susceptible. In the former two cases, resistance in UI 320 and PI 439534 would be allelic and, in the third situation, it would be nonallelic. If one assumes that occurrence of nine white mold-susceptible plants in the $\mathrm{F}_{2}$ reflected residual variability in UI 320 or PI 439534, then it is plausible that the white mold resistance in both UI 320 and PI 439534 was allelic and the allele in PI 439534 was dominant over the UI 320 allele.

$P$. vulgaris is highly self pollinating, often with $<1 \%$ outcrossing in most environments. Thus, variation for white mold reaction in Othello and UI 320 could be due largely to the fact that they were never selected under white mold pressure. In contrast, as noted earlier, $P$. coccineus is often cross pollinating; thus, some variation for one or more characters within each accession may be expected. Although hybridization between $P$. vulgaris and $P$. coccineus is effected without the use of embryo rescue, production of large quantities of hybrid seed, especially in the green-

Table 2. White mold reaction of pinto bean cvs. Othello and UI 320 and Phaseolus coccineus L. accessions PI 433246 and PI 439534, and their $\mathrm{F}_{1}, \mathrm{~F}_{2}$, and backcrosses evaluated in the greenhouse at Fort Collins, CO in 2004 using the straw test ${ }^{\mathrm{a}}$

\begin{tabular}{|c|c|c|c|c|}
\hline \multirow[b]{2}{*}{ Genotype } & \multicolumn{4}{|c|}{ White mold reaction ${ }^{b}$} \\
\hline & Mean & No. of plants & Ratio $^{c}$ & $P$ value \\
\hline Parent-Othello & 7.9 & 33 & $\ldots$ & $\ldots$ \\
\hline Parent-PI 433246 & 3.4 & 21 & $\ldots$ & $\ldots$ \\
\hline \multicolumn{5}{|l|}{ Othello/PI 433246} \\
\hline $\mathrm{F}_{1}$ & 4.0 & 16 & $\ldots$ & $\ldots$ \\
\hline $\mathrm{F}_{2}($ Colorado $)$ & $\ldots$ & 31 & 24R:7S & 0.76 \\
\hline $\mathrm{F}_{2}$ (Idaho) & $\ldots$ & 15 & $12 \mathrm{R}: 3 \mathrm{~S}$ & 0.65 \\
\hline $\mathrm{F}_{2}($ pooled $)$ & 4.7 & 46 & 36R:10S & 0.61 \\
\hline Othello²//PI433246 & 7.4 & 34 & 7R:27S & 0.0006 \\
\hline Parent-UI 320 & 3.2 & 36 & $\ldots$ & $\ldots$ \\
\hline Parent-PI 439534 & 2.1 & 38 & $\ldots$ & $\ldots$ \\
\hline \multicolumn{5}{|l|}{ UI 320/PI 439534} \\
\hline $\mathrm{F}_{1}$ & 2.6 & 10 & $\ldots$ & $\ldots$ \\
\hline $\mathrm{F}_{2}($ Colorado $)$ & $\ldots$ & 26 & 20R:6S & 0.82 \\
\hline $\mathrm{F}_{2}$ (Idaho) & $\ldots$ & 13 & $10 \mathrm{R}: 3 \mathrm{~S}$ & 0.87 \\
\hline $\mathrm{F}_{2}($ pooled $)$ & 4.2 & 39 & 30R:9S & 0.78 \\
\hline UI $320^{2} / /$ PI 439534 & 3.1 & 31 & 30R:1S & 0.00 \\
\hline
\end{tabular}

${ }^{a}$ The two $\mathrm{F}_{2}$ also were evaluated using the modified petiole test at Kimberly, ID in 2004.

${ }^{b}$ Sclerotinia isolate CO-S20 collected from pinto bean was used to inoculate seedlings in a greenhouse on a mist bench covered by plastic at 20 to $23^{\circ} \mathrm{C}$ with diffuse lighting. Reactions were scored on a 1to- 9 scale at 5 to 7 days post-inoculation, where $1=$ symptomless and $9=$ severely diseased. Subsequently, plants with scores of 1 to 5 were grouped as resistant and 6 to 9 as susceptible for the $F_{2}$ and backcrosses.

${ }^{\mathrm{c}} \mathrm{R}=$ resistant, and $\mathrm{S}=$ susceptible. 
house at higher latitudes, is not easy. Thus, the relatively small population size also may have contributed to the distorted segregation.

In susceptible $\times$ resistant $P$. coccineus crosses, one $F_{1}$ was susceptible whereas another $F_{1}$ segregated into 3:2 resistant:susceptible (18). Two or three recessive genes controlled white mold resistance in the cross that had susceptible $F_{1}$. The $F_{2}$ from the resistant $F_{1}$ segregated into 68:11 susceptible:resistant. Abawi et al. (1) reported a single dominant allele that controlled resistance to white mold in a $P$. vulgaris/P. coccineus population. It is interesting to note that this resistance from B-3749, a selection from $P$. coccineus PI 175829, was expressed in blossoms that did not become colonized after inoculation with ascospores of $S$. sclerotiorum. Our study also indicates the existence of single dominant allelic resistance in $P$. coccineus accessions PI 433246 and PI 439543, and the resistance was expressed in the stem and petiole inoculated with mycelial plugs. Resistance in the stem also was reported by Chipps et al. (2) in other $P$. coccineus accessions, and the mechanism of resistance is believed to be due to the presence of lower concentrations of oxalate.

Future work should investigate the performance of our resistant $P$. coccineus and interspecific breeding lines when exposed at different growth stages to different types of inoculum under varying environmental conditions $(6,7)$. These resistant and intermediate parents and selected interspecific breeding lines should be useful for future improvement of white mold resistance of pinto and other market classes of dry and green bean.

\section{ACKNOWLEDGMENTS}

Financial support was provided by the Colorado Dry Bean Administrative Committee, Colorado Seed Growers Association, and USDA-ARS National Sclerotinia Initiative Grant No. 58-5442-2256, entitled "Introgressing White Mold Resistance from the Secondary Gene Pool of Common Bean."
We thank M. Welsh, Phaseolus collection curator, for supplying seed of 13 P. coccineus accessions.

\section{LITERATURE CITED}

1. Abawi, G. S., Provvidenti, R., Crosier, D. C., and Hunter, J. E. 1978. Inheritance of resistance to white mold disease in Phaseolus coccineus. J. Hered. 69:200-202.

2. Chipps, T. J., Gilmore, B., Myers, J. R., and Stotz, H. U. 2005. Relationship between oxalate, oxalate oxidase activity, oxalate sensitivity, and white mold susceptibility in Phaseolus coccineus. Phytopathology 95:292-299.

3. del Rio, L. E., Kurtzweil, N. C., and Grau, C. R. 2001. Petiole inoculation as a tool to screen soybean germplasm for resistance to Sclerotinia sclerotiorum. (Abstr.) Phytopathology 91:S176.

4. Genchev, D., and Kiryakov, I. 2002. Inheritance of resistance to white mold disease (Sclerotinia sclerotiorum (Lib.) de Bary) in the breeding line A 195 of common bean (Phaseolus vulgaris L.). Bulg. J. Agric. Sci. 8:181-187.

5. Gilmore, B., Myers, J. R., and Kean, D. 2002. Completion of testing of Phaseolus coccineus plant introductions (PIs) for white mold, Sclerotinia sclerotiorum, resistance. Annu. Rep. Bean Improv. Coop. 45: 64-65.

6. Hall, R., Phillips, L. G., and Mooij, D. 1999. Field and greenhouse evaluation of the straw test for resistance of dry bean to white mold. Annu. Rep. Bean Improv. Coop. 42:55-56.

7. Hall, R., Phillips, L. G., Mooij, D., and Madariaga-N, A. 2000. Relationships in the field between measures of white mold on white bean following natural infection and inoculation by the straw method. Annu. Rep. Bean Improv. Coop. 43:152-153.

8. Kerr, E. D., Steadman, J. R., and Nelson, L. A. 1978. Estimation of white mold disease reduction of yield and yield components of dry edible beans. Crop Sci. 18:275-279.

9. Kolkman, J. M., and Kelly, J. D. 2000. An indirect test using oxalate to determine physiological resistance to white mold in common bean. Crop Sci. 40:281-85.

10. Kolkman, J. M., and Kelly, J. D. 2003. QTL conferring resistance and avoidance to white mold in common bean. Crop Sci. 43:539-548.

11. Kull, L. S., Vuong, T. D., Powers, K. S., Eskridge, K. M., Steadman, J. R., and Hartman, G. L. 2003. Evaluation of resistance screening methods for Sclerotinia stem rot of soybean and dry bean. Plant Dis. 87:14711476.

12. Miklas, P. N., Delorme, R., Hannan, R., and Dickson, M. H. 1999. Using a subsample of the core collection to identify new sources of resistance to white mold in common bean Crop Sci. 39:569-573

13. Miklas, P. N., Delorme, R., and Riley, R. 2003. Identification of QTL conditioning resistance to white mold in snap bean. J. Am. Soc. Hortic. Sci. 128:564-570.

14. Miklas, P. N., Grafton, K. F., Kelly, J. D., Schwartz, H. F., and Steadman, J. R. 1998 Registration of four white mold resistant dry bean germplasm lines: I9365-3, I9365-5, I9365-31, and 92BG-7. Crop Sci. 38:1728.

15. Miklas, P. N., Hauf, D. C., Henson, R. A., and Grafton, K. F. 2004. Inheritance of ICA-Bunsiderived resistance to white mold in a navy $\times$ pinto bean cross. Crop Sci. 44:1584-1588.

16. Miklas, P. N., Johnson, W. C, Delorme, R., and Gepts, P. 2001. QTL conditioning physiological resistance and avoidance to white mold in dry beans. Crop Sci. 41:309-315.

17. Myers, J. R., Gilmore, B., and Kean, D. 1999. Correlation between the field and straw test for white mold resistance in common bean. Annu. Rep. Bean Improv. Coop. 42:57-58.

18. Myers, J. R., and Stotz, H. U. 2002. Progress in genetic analysis of white mold resistance in Phaseolus coccineus. USDA Sclerotinia Initiative Annual Report. Online publication.

19. Park, S. O., Coyne, D. P., Steadman, J. R., and Skroch, P. W. 2001. Mapping of QTL for resistance to white mold disease in common bean. Crop Sci. 41:1253-1262.

20. Petzoldt, R., and Dickson, M. H. 1996. Straw test for resistance to white mold. Annu. Rep. Bean Improv. Coop. 39:142-143.

21. Schwartz, H. F., Casciano, D. H., Asenga, J. A., and Wood, D. R. 1987. Field measurement of white mold effects upon dry beans with genetic resistance or upright plant architecture. Crop Sci. 27:699-702.

22. Singh, S. P. 1982. A key for identification of different growth habits of Phaseolus vulgaris L. Annu. Rep. Bean Improv. Coop. 25:92-95.

23. Singh, S. P., and Schwartz, H. F. 2006. Introgressing white mold resistance from the secondary gene pool of dry bean. Page 23 in: Proc. 4th Annu. Meet. USDA Sclerotinia Initiative, Minneapolis, MN

24. Steadman, J. R. 1983. White mold: a serious yield-limiting disease of bean. Plant Dis. 67:346-350.

25. Steadman, J., Eskridge, K., Costa, J., Grafton, K., Kelly, J., Kmiecik, K., Kolkman, J., Myers, J., and Miklas, P. 2001. Evaluation of sources of resistance to Sclerotinia sclerotiorum in common bean with five test methods at multiple locations. Annu. Rep. Bean Improv. Coop. 44:89-90. 